\title{
Dimensioning of nursing professionals: implications for the work process in the family health strategy
}

\author{
Dimensionamento de profissionais de enfermagem: implicaçōes para o processo de trabalho na \\ estratégia saúde da família \\ Dimensionamiento de profesionales de enfermería: implicaciones para el proceso de trabajo en la \\ estrategia salud de la familia
}

\author{
Lucas Cardoso dos Santos ${ }^{1}$ \\ Juliane Andrade ${ }^{2}$
}

Wilza Carla Spiri ${ }^{1}$

\begin{abstract}
1. Universidade Estadual Paulista "Júlio de Mesquita Filho", Botucatu, SP, Brasil.

2. Universidade de Brasília, Distrito Federal, DF, Brasil.
\end{abstract}

Corresponding author

Lucas Cardoso dos Santos.

E-mail: lucascardoso_santos@yahoo.com.br.

Submitted on $11 / 27 / 2018$.

Accepted on 04/03/2019.

DOI: 10.1590/2177-9465-EAN-2018-0348

\begin{abstract}
Objective: To report the experience of the construction of nursing dimensioning and its implications for the working process in a Family Health Unit (FHU). Method: Descriptive report, which used the recommendations of Resolution No. 543/2017 of the Federal Nursing Council to dimension the number of nursing professionals from a FHU with two teams in the interior of São Paulo. Results: The dimensioning evidenced the lack of the nurse and nursing assistant and brought implications for the work process, such as systematization of information about nursing staff absences, adequacy and monitoring of the information system and reorganization of the area of service coverage. Conclusion and implications for practice: It is important that nurses use management tools, such as dimensioning, to seek changes in the nursing and staff work and in the improvement of care offered. Staff dimensioning proved to be satisfactory for the adaptations in the work process.
\end{abstract}

Keywords: Dimensioning of Personnel; Primary Health Care; Professional practice management; Nursing

\section{Resumo}

Objetivo: Relatar a experiência da construção do dimensionamento de enfermagem e suas implicações para o processo de trabalho em uma Unidade de Saúde da Família (USF). Método: Relato descritivo, que utilizou as recomendações da Resolução no 543/2017 do Conselho Federal de Enfermagem para dimensionar o número de profissionais de enfermagem de uma USF com duas equipes no interior paulista. Resultados: $O$ dimensionamento evidenciou a falta do enfermeiro e do auxiliar de enfermagem e trouxe implicações para o processo de trabalho, como sistematização de informações sobre ausências da equipe de enfermagem, adequação e monitoramento do sistema de informação e reorganização da área de abrangência do serviço. Conclusão e implicações para a prática: É importante que o enfermeiro utilize instrumentos gerenciais, tais como o dimensionamento, visando buscar mudanças no trabalho da enfermagem e equipe e na melhoria da assistência ofertada. $O$ dimensionamento de pessoal mostrou-se satisfatório para as adequações no processo de trabalho.

Palavras-chave: Dimensionamento de pessoal; Atenção Primária à Saúde; Gerenciamento da prática profissional; Enfermagem.

\section{Resumen}

Objetivo: Relatar la experiencia de la construcción del dimensionamiento de enfermería y sus implicaciones para el proceso de trabajo en una Unidad de Salud de la Familia (USF). Método: Relato descriptivo, que utilizó recomendaciones de la Resolución 543/2017 del Consejo Federal de Enfermería para dimensionar el número de profesionales de enfermería de una USF con dos equipos en el interior paulista. Resultados: El dimensionamiento evidenció la falta del enfermero y del auxiliar de enfermería y trajo implicaciones para el proceso de trabajo, como sistematización de informaciones sobre ausencias del equipo de enfermería, adecuación y monitoreo del sistema de información y reorganización del área de cobertura del servicio. Conclusión e implicación para la práctica: Es importante que el enfermero utilice instrumentos gerenciales, como el dimensionamiento, buscando cambios en el trabajo y en la mejora de la asistencia ofrecida. El dimensionamiento se mostró satisfactorio para las adecuaciones en el proceso de trabajo.

Palabras clave: Dimensionamiento de Profesionales; Atención Primaria a la Salud; Gestión de la práctica profesional; Enfermería. 


\section{INTRODUCTION}

Nursing work encompasses five dimensions: assisting; managing; researching; political participation; and teaching; which can be performed concomitantly in a complementary and interdependent way, so that each dimension presents its own elements (object, means/instruments and activity). ${ }^{1}$

As coordinator of the caring process, it is indispensable for the nurse to apply tools in the dynamics of care and service so that an effective and efficient practice can take place in any of the dimensions of their work, for example, to use management tools that can achieve the proposed objectives. ${ }^{2}$

One of these tools is the dimensioning of personnel in nursing, fundamental for the adequate forecasting of professionals, quantitatively and qualitatively, aiming to attend to the needs of the assisted population in consonance with the particularity of the different health services scenarios, in order to provide quality to assistance, aiming the safety of users and workers. ${ }^{3}$

In the area of health, the nursing team represents the majority of professionals and has advanced in the personnel dimensioning references, especially in the hospital environment, finding support and guidelines in the resolutions of the Federal Nursing Council ("COFEN"), promulgated, as of the year 1996, with the Resolution 189/19964, updated in 2004 (Resolution 293/2004) and in 2016 (Resolution 527/2016). ${ }^{6}$ Recently, COFEN revoked the latter one and published Resolution 543/2017, which includes specific parameters for different services, including Primary Health Care (PHC). ${ }^{7,8}$

The criteria used in this update for the nursing staff dimensioning in the $\mathrm{PHC}$ context comes from a study that concluded that in this level of attention to the users assisted, depending on the characteristics of each unit, they might present different health needs, showing how complex is assistance in this context. ${ }^{7,8}$

On the other hand, the National Policy on Basic Attention (NPBA), recently updated (2017), indicates a step backwards by allowing a "flexibilization of population coverage" by a team, which is related, among other reasons, to "the parameters of the team/population", to "the specificities of the territory" and to "the possibility of other additional arrangements", with different population parameters, which may have a reach "greater or lesser than the recommended parameter", making the quantitative of professionals undefined, previously assured by PNAB 2011. ${ }^{9}$

At this conjuncture, the quantitative planning of the nursing team is not only related to the ethical and political factors, but also to the economic and social factors that form the basis of the health system. Thus, the importance of dimensioning lies in the potential of seeking a balance between the availability of services, population needs, the goals, policies and health programs. $8,10,11$

Considering the importance of the nursing staff dimensioning, as well as the specificities of PHC and the scarcity in the literature on the subject in this context of acting, this article aims to collaborate with the knowledge in this area, reducing the existing gap, since it presents theoretical/scientific content and practical applicability when reporting the experience of the construction of the nursing personnel dimensioning and its implication for the work process in a Family Health Unit (FHU), thus answering the following questions: What is the result of the dimensioning of nursing personnel in the FHU in study? What is the contribution of the nursing staff dimensioning to the work process in the application scenario?

\section{METHOD}

\section{Type of study}

This is an experience report with a descriptive character, which has used the recommendations suggested in COFEN Resolution 543/2017 to dimension the number of nursing professionals of a FHU. ${ }^{7}$

The action that resulted in this report was the product of an inspection carried out by the Regional Nursing Council of São Paulo (COREN-SP), held in December 2017, in which some annotations were made, among them, the need to adequately dimension the nursing staff of the health unit, field of this study, since it was not yet constructed, considering the recommendations of the Resolution of $2017 .{ }^{7}$

\section{Scenario of the study}

The health service in study is part of the Health Care Network of a city in the Midwest of the state of São Paulo with a total population of approximately 144,820 inhabitants ${ }^{12}$, of which $41.1 \%$ are covered by 12 units in the model Family Health and $58.9 \%$ are covered by six Basic Health Units (BHU), in the traditional model, and two School-based Health Centers (SBHC). ${ }^{13,14}$

The FHU is managed by a Social Health Organization (SHO). The $\mathrm{BHU}$ and the $\mathrm{SBHC}$ are under the management, respectively, of the Municipal Health Department and of a Public Institution of Higher Education.

The FHU, where this experiment was carried out, was inaugurated in 2003, but previously it operated as a BHU. It is located at the eastern end of the urban area of the municipality and among users attended are those who are hypertensive, diabetic, obese, unemployed, users of legal and illegal drugs, and victims of domestic violence, among others.

The FHU coverage area has approximately 10,204 users, who are assisted by two family health teams, consisting of: two general service helpers; two administrative assistants; two nurses; seven nursing assistants; two doctors; one doctor from Mais Médicos Brazilian Program; two dental surgeons; two dental assistants; one pharmacy assistant; one pharmacist and; seven Community Health Agents (CHA). Of the seven nursing assistants, four were hired as nursing assistants, with professional registration in COREN-SP of nursing technicians.

Most of the employees had a weekly workload of 40 hours, with the exception of the pharmacist (12 hours) and the doctor of the Mais Médicos Brazilian Program (32 hours). In relation to the first, it is necessary to elucidate that the municipality is divided into large regions and that its workload is divided between these. The doctor linked to the Mais Médicos Brazilian Program follows the scheme of the program, which determines 32 hours 
of work in the health unit and eight hours for a directed study. ${ }^{15}$

The coverage territory of the unit is divided into two areas, subdivided into five micro areas and half of the professionals in each category make up a micro area, with the exception of nursing auxiliaries, in which three make up Team 1 (T1) and four, Team 2 (T2), and of $\mathrm{CHA}$, where four are from $\mathrm{T} 1$ and three from $\mathrm{T} 2$, which results in micro areas that are unassisted by the latter professional.

In this context, it is worth mentioning that the administrative assistants, nursing assistants, pharmacists, pharmacy assistants and doctors of the Mais Médicos Brazilian Program attend users independently of the area/team. Users' consultations with medical professionals, nurses and dental surgeons are scheduled taking into account the area where they live. And, the spontaneous demand services performed do not follow this division, that is, the T1 doctor, for example, can serve the user residing in the T2 reference area.

\section{Collection, organization and analysis of data}

Data collection, organization and analysis were based on COFEN Resolution 543/2017 ${ }^{7}$ and occurred between January and March of 2018, with data referring to the year 2017.

All of this process was guided by five steps: 1) delimitation of the professional categories for which is intended dimensioning the calculation of the Available Work Time (AWT) in the year by professional category and team;2) calculation of the number of professionals by professional category and team to carry out the direct interventions; 3 ) calculation of the number of professionals by professional category and team to perform indirect interventions; 4) calculation of the number of workers by professional category and team; and 5) interpretation of results. ${ }^{7}$

Initially, for the execution of step one, the professional categories for nursing dimensioning were selected: nursing assistants and nurses, and the AWT that expresses the time that each professional category requires for, in a year, to perform its work. Considering the expected and unplanned absences, it is calculated from the formula: AWT $=[A-(B+C+D+E)] \times h{ }^{7}$

The variables $A, B, C, D, E, h$ represent: $A$ - the number of working days possible in a year; $B$ - number of days of absence due to holidays in one year; $\mathrm{C}$ - number of days of absence due to vacation in one year; $D$ - number of days of absences due to medical leave in one year; $E$ - number of days of absence due to other licenses in one year; $h$ - number of hours worked in one day. ${ }^{7}$

For the calculation of variable $A$, it was sufficient to multiply the number of weeks that compose a year (52 weeks) by the number of working days of a week (five working days), which resulted in the value 260 and, to find the values of the variables $B$, $C, D$ and $E$, it was necessary to request to the Human Resources (HR) sector, in this case the variable $h$ presented the value eight. ${ }^{7}$

The second step was obtained by calculating the number of direct interventions (Qdir), expressed by the equation - Qdir $=\{[(\mathrm{P} 1 \mathrm{X}$ T1 $) / \mathrm{AWT})]+[(\mathrm{P} 2 \mathrm{X} \mathrm{T} 2) / \mathrm{AWT}]+[(\mathrm{P3} \times \mathrm{T} 3) / \mathrm{AWT})$ ... ] $\}$ - Where $P$ (production) corresponds to the total amount of direct care interventions performed by the professional category: attending to spontaneous demand; nursing consultations; administration of medications; performing outpatient procedures; assessment of vital signs and anthropometric measurements; venipuncture; home visits and promotion of educational activities. ${ }^{7}$

In order to obtain the values of $\mathrm{P}$, numerous reports were generated, considering the Public Management Information System used by the municipality (Vivver), the Health Information System of the Ministry of Health (e-SUS), the information provided by the $\mathrm{HR}$ sector and the information of the Program of Improvement to the Access and Quality in the Basic Attention (PIAQ). Regarding the value of $T$ (time) it is related to the average time, in hours, spent to carry out each intervention, having as basis stratum 5 , defined by PIAQ. ${ }^{7}$

It is important to remember that direct interventions consist of actions that require interaction with the user/family/community and are carried out by all members of a professional category and who, in particular, specify the work in the $\mathrm{PHC}^{7}$; and that direct intervention "nursing consultation" is exclusive to the nurse.

The third step - calculation of the number of professionals by professional category and team to perform the indirect interventions (Qind) - uses the stratum 5 defined by the PIAQ with equal values for the two teams and refers to an estimate of nursing professionals necessary to carry out indirect care interventions: educational actions of health work; infection control; control of supplies; organization of work process; documentation; interpretation of laboratory data; mapping and territorialization; reference and counter-reference; administrative meeting; meeting for the evaluation of professional care; supervision of the unit's work; exchange of information on health care; health surveillance and indirect occasional. ${ }^{7}$

The next step - calculation of the number of workers by professional category and team (Q) - made use of the equation?:

$$
Q=\frac{Q d i r}{1-\frac{Q i n d \%}{100}}
$$

The last step consisted in the interpretation of the data in the course of which the FHU's manager nurses analyzed and interpreted, considering the work process of the service.

\section{RESULTS}

The values found for the number of nursing professionals by professional category - Nursing $(\mathrm{N})$ and Auxiliary Nursing / Nursing Technician (AN/NT) - and team - T1 and T2 - demonstrated a difference in the number of nursing professionals that would be necessary to perform the entire work process involved in the service analyzed, as explained in Table 1, where the difference between the number of professionals dimensioned (Qdimensioned) and the number of working professionals (Qactual) in the two teams is shown.

In the results found, there was a need to hire three and two nurses in T1 and T2, respectively, to perform all activities carried out by this professional category. And, for T1, it would be neces- 
Table 1. Comparative description between the quantity of professionals dimensioned and acting by professional category and team, Botucatu, SP, 2018

\begin{tabular}{|c|c|c|c|}
\hline & Qdimensioned* & Qactual $^{\S}$ & $\begin{array}{c}\text { Qdimensioned - } \\
\text { Qactual }\end{array}$ \\
\hline N1† & 3 & 1 & 2 \\
\hline $\mathbf{N 2 +}$ & 2 & 1 & 1 \\
\hline AN/NT1 ¥ & 4 & 3 & 1 \\
\hline AN/NT2 $\ddagger$ & 4 & 4 & 0 \\
\hline \multicolumn{4}{|c|}{ * Number of professionals dimensioned } \\
\hline \multicolumn{4}{|c|}{$\S$ Number of professionals involved; } \\
\hline \multicolumn{4}{|l|}{ † Team (1 or 2$)$} \\
\hline
\end{tabular}

sary to hire another nursing assistant, different from T2, since the number of four professionals in this category contemplates the stipulated according to the dimensioning done. Thus, it was found that there was a deficit in the number of nursing professionals of upper and middle level in the two FHU teams, except for T2 medical professionals.

During the construction of the dimensioning, key points were identified to facilitate the annual application of this tool and, also, to adapt the work process in the FHU, which will be exposed below.

One of the first obstacles identified to collect the data for the construction of the first dimensioning stage was that nurses and, also in the company's HR sector, did not have systematized information about planned and unplanned absences. From then on, this information has been tabulated by HR, considering that, each year, the nursing staff should be dimensioned, having as a reference, always the previous year.

Another point of this stage is related to the occurrence of nursing professionals hired as nursing auxiliaries, but registered in the labor council as nursing technicians. The nurses then made a letter to the PHC Coordination and also to COREN-SP informing them that such professionals had been advised of this need, however without further governability.

Attention is drawn to this fact, since there are employees performing functions different from the position for which they were hired, and it affects the labor principles, since it involves questions such as deviation of function, salary below that offered and not hiring adequate labor for the function.

As regards to the second stage, when checking the reports provided by the information systems (e-SUS and Vivver), it was observed that there was a discrepancy in the number of interventions performed in relation to what actually happened in the unit, such as, for example, the number of nursing visits and vital signs measurements and anthropometric measurements, in which were expected high numbers, and for outpatient procedures such as home visits and low health promotion activities, low numbers. Therefore, it was found that the proportion of interventions provided by the system was not as expected.
Based on this finding, two hypotheses were initially raised: the first one related to the incorrect inputting in of the system, and the second associated with the lack of inputting in the system.

Considering these two hypotheses, during the team meetings, a conversation was held with all FHU professionals so that difficulties in using the system, which were or would be identified, could be pointed out and ways were built with the objective of avoiding possible failures in the records of the assistance provided.

At that time, it was clear that many records were only being made in patients' medical charts and in handwritten record books. The importance of the records as attribution of nursing was discussed, as well as the existence of work overload, a frequent report of the nursing team.

The team then proposed that each service sector manually recorded the direct interventions performed so that the values found in the Vivver and e-SUS reports could then be confronted with the manual annotations. With this strategy, differences were found and the Information Technology sector and the Municipal Health Department Coordination were communicated, aiming at possible adjustments and repairs to the system, which occurred later.

It is worth mentioning that, after these dialogues and measures, the entire team maintained the monitoring of the data through monthly reports and manual records for checking and crossing the data, in order to diagnose, as soon as possible, inadequacies not only in the reports generated by the system, as well as in the recording of information.

Still, regarding the values found for the direct interventions, and considering that the two nurses had the same weekly workload and the same number of vacancies for the scheduled appointments, these professionals had to look for possible hypotheses for the difference found in the variables: attending to spontaneous demand, nursing consultation, administration of medication, outpatient procedures, home visits and promotion of educational actions.

After being identified that the nurse of the $\mathrm{T} 1$ had greater work demand, not previously perceived, a new discussion was made in the space of the team meeting in which the CHA had a relevant role, since they pointed out the existence of a considerable difference of registered users and families by team, being greater in T1, which entailed a greater demand of work for this team. Thus, a new process of division of the areas was carried out, with primordial and active participation of the $\mathrm{CHA}$, resulting in the relocation of two micro areas from $\mathrm{T} 1$ to $\mathrm{T} 2$.

In order to redistribute the micro areas among the teams, the following criteria were used: proximity of the micro area that would be transferred to the area that would be integrated, characteristics of the registered users of each micro area, $\mathrm{CHA}$ 's surveyed health demands by micro area and the own characteristics of the territory.

In this context, it should be mentioned that, in addition to the work overload found and expressed in the variables of direct 
interventions between the teams, the FHU of the municipality in question has one nurse per team for the execution of management and assistance activities.

\section{DISCUSSION}

The data generated provided important information about the work process of the whole unit and not only, specifically, the nursing team. In this sense, the nurses of the service played a crucial role in analyzing them, in order to improve their management and care practices, with repercussions on the work process, teamwork and care provided.

That said, it is important to consider the importance of services and professionals to understand, with greater clarity, the role of inspections in health establishments, professional or non-professional, that seek to ensure adequate working conditions for both professionals and users assisted.

It is worth noting that the scale proposed by COFEN Resolution $2017(543 / 2017)^{7}$, which foresees this instrument, is not yet applied throughout the national territory, thus, the importance of the actions of COREN-SP, a supervisory body for professional practice which has as premise the participatory and educational action, to value ethical issues and the nursing process, according to COFEN Resolution 374/2011. ${ }^{16}$

However, the lack of professionals detected by the dimensioning process is not in the team's governance, and it is therefore essential to elaborate joint management strategies of the higher instances, since the lack of staffing affects the safety of the worker and of the user and the quality of health care offered. ${ }^{17}$

Regarding the implications of the work process in the application of the nursing personnel dimensioning, in this scenario, specifically, were: adequacy in the inputting of the information system / monitoring of the recorded data and reorganization of the area of service coverage.

In this perspective, there is a study that characterized the activities developed by the nurses of a FHU in a municipality of the South of Brazil and found that the inputting of the information system was the activity which had highest occurrence in the FHU, thus, they emphasize the importance of this activity in the work process of a health service, because it is a tool that provides support for decision making, with emphasis on the process of care, management and evaluation/monitoring, not only in the health unit, but at all levels of care that makes up the Unified Health System (UHS). ${ }^{1}$ It is also necessary to guarantee the quality of the information so that the interpretation of the data is adequate, aiming at the quality of health care $^{18}$, which was taken into account by the $\mathrm{FHU}$ team when identifying the inadequacy of the data and proposing its monitoring.

Thus, it was observed that the team meeting was an important apparatus in this study, by making possible the joint decision-making and being a space for exchange, dialogue and resolution of identified problems, as well as for making possible the planning of teamwork, monitoring actions and carrying out educational activities, which contributes to meeting the health needs of the population enrolled in $\mathrm{FHU}{ }^{1}$
In addition to the way information was recorded and monitoring of these actions, the team meeting was also fundamental for redistribution of the territory. In both, the importance of the interprofessional involvement and the relevance in the role of the nurse for promoting this moment was demonstrated, articulating the various professional categories with focus on the provided care. ${ }^{19}$

Therefore, it is guaranteed the operationalization of the work, not only of nursing, but of the team involved in health work ${ }^{11}$, since it raises the consensus of all in the redistribution of area and improvement in the distribution of the population attended by each team/nurse.

Thus, the relevance of this tool, personnel dimensioning, in the management of the care process is reinforced, since its content is appropriate to support the need for assistance ${ }^{3}$ of the assigned community, in the case of PHC, since it anticipates the adequate quantification of the nursing staff, and, consequently, enables the quality of care.

\section{FINAL CONSIDERATIONS}

In summary, the present report reinforces the importance of nursing dimensioning in the scope of the PHC, which, in the context presented, brought a change of attitude of the team to register the data correctly in the information system and use the team meeting space as a field powerful for collective decision making, which generated the redistribution of territory among the teams.

Thus, this article, in its reporting category, can contribute to the realities of other $\mathrm{FHU}$, since the use of personnel dimensioning in the said context proved to be satisfactory regarding the adjustments of the work process.

Because it is an experience report, other studies are recommended which can establish scientific evidence on the implications of the nursing staff dimensioning in the work process in the $\mathrm{PHC}$, given the importance of this issue for the quality of care and health of the worker.

\section{REFERENCES}

1. Paula M, Peres AM, Bernardino E, Eduardo EA, Sade PMC, Larocca LM. Características do processo de trabalho do enfermeiro da estratégia de saúde da família. Rev Min Enferm [Internet]. 2014 Jun;18(2):454-70. Available from: http://www.dx.doi.org/10.5935/1415-2762.20140034

2. Oliveira AS, Almeida ML, Santos MF, Zilly A, Peres AM, Rocha FLR Ferramentas gerenciais na prática de enfermeiros da atenção básica em saúde. Rev Adm Saúde [Internet]. 2017; [cited 2019 Jan 21]; 17(69):[approx. 20 slides]. Available from: http://dx.doi.org/10.23973/ras.69.64

3. Fugulin FMT, Gaidzinski RR, Lima AFC. Dimensionamento de Pessoa de Enfermagem em Instituições de Saúde. In: Kurcgant P, coord Gerenciamento em Enfermagem. $3^{\mathrm{a}}$ ed. Rio de Janeiro (RJ): GuanabaraKoogan; 2016. p. 115-27.

4. Conselho Federal de Enfermagem (COFEN) (BR). Resolução COFEN № 189/1996, de 25 de março de 1996 (BR). Estabelece parâmetros para dimensionamento do quadro de profissionais de enfermagem nas instituições de saúde. Brasília (DF): Conselho Federal de Enfermagem (COFEN) [Internet]; 1996 [cited 2018 Sep 13]. Available from: http:// www.cofen.gov.br/resoluo-cofen-1891996-revogada-pela-resoluocofen-2932004_4249.html 
5. Conselho Federal de Enfermagem (COFEN) (BR). Resolução COFEN № 293/2004, de 21 de setembro de 2004. Fixa e estabelece parâmetros para dimensionamento do quadro de profissionais de enfermagem nas unidades assistenciais das instituições de saúde e assemelhados. Brasília (DF): Conselho Federal de Enfermagem (COFEN) [Internet]; 2004 [cited 2018 Sep 13]. Available from: http://www.cofen.gov.br/ resoluo-cofen-2932004_4329.html

6. Conselho Federal de Enfermagem (COFEN) (BR). Resolução COFEN № 527/2016, de 03 de novembro de 2016. Atualiza e estabelece parâmetros para o Dimensionamento do Quadro de Profissionais de Enfermagem nos serviços/locais em que são realizadas atividades de enfermagem. Brasília (DF): Conselho Federal de Enfermagem (COFEN) [Internet]; 2016 [cited 2018 Sep 13]. Available from: http:// www.cofen.gov.br/resolucao-cofen-no-05272016_46348.html

7. Conselho Federal de Enfermagem (COFEN) (BR). Resolução COFEN №543/2017, de 18 de abril de 2017. Atualiza e estabelece parâmetros para o Dimensionamento do Quadro de Profissionais de Enfermagem nos serviços/locais em que são realizadas atividades de enfermagem. Brasília (DF): Conselho Federal de Enfermagem (COFEN) [Internet]; 2017 [cited 2018 Sep 13]. Available from: http://www.cofen.gov.br/ resolucao-cofen-5432017_51440.html

8. Bonfim D, Gaidzinski RR, Santos FM, Gonçales CS, Fugulin FMT. Identificação das intervenções de enfermagem na Atenção Primária à Saúde: parâmetro para o dimensionamento de trabalhadores. Rev Esc Enferm USP [Internet]. 2012; [cited 2018 Sep 13]; 46(6):1462-70. Available from: http://dx.doi.org/10.1590/S0080-62342012000600025

9. Morosini MVGC, Fonseca AF, Lima LD. Política Nacional de Atenção Básica 2017: retrocessos e riscos para o Sistema Único de Saúde. Saúde Debate [Internet]. 2018 [cited 2018 Oct 18]; 42(116):1124. Available from: http://www.scielo.br/scielo.php?pid=S010311042018000100011\&script=sci_abstract\&tlng=pt

10. Bonfim D, Fugulin FMT, Laus AM, Peduzzi M, Gaidzinski RR. Time standards of nursing in the Family Health Strategy: an observational study. Rev Esc Enferm USP [Internet].2016 Dec;50(1):118-26. Available from: http://dx.doi.org/10.1590/S0080-623420160000100016

11. Bonfim D, Pereira MJB, Pierantoni CR, Haddad AE, Gaidzinski RR. Instrumento de medida de carga de trabalho dos profissionais de Saúde na Atenção Primária: desenvolvimento e validação. Rev Esc Enferm USP [Internet]. 2015 Feb;49(Esp2):25-34. Available from: http:/ dx.doi.org/10.1590/S0080-623420150000800004
12. Instituto Brasileiro de Geografia e Estatística (BR). Cidades [Internet] Rio de Janeiro: IBGE; 2018 [cited 2018 Sep 23]. Available from https://cidades.ibge.gov.br/brasil/sp/botucatu/panorama

13. Botucatu. Unidades de Saúde [Internet]. Botucatu: Secretaria Municipal de Saúde; 2017 [cited 2017 Apr 18]. Available from: http:// saude.botucatu.sp.gov.br/

14. Botucatu. Cobertura da Atenção Básica. Núcleo de Tecnologia da Informação- NDI- DAB; 2018 [cited 21 May 2018]. Available from: http://sage.saude.gov.br

15. Presidência da República (BR). Lei $n^{\circ} 12.871$, de 22 de outubro de 2013 (BR). Dispõe sobre a instituição do Programa Mais Médicos, altera as Leis $\mathrm{n}^{\circ} \mathbf{8 . 7 4 5}$, de 9 de dezembro de 1993, e nำ6.932, de 7 de julho de 1981, e dá outras providências. Brasília (DF): Diário Oficial da União [Internet]; 2013 [cited 2019 Jan 20]. Available from: http:// www.planalto.gov.br/ccivil_03/_Ato2011-2014/2013/Lei/L12871.htm

16. Conselho Federal de Enfermagem (COFEN) (BR). Resolução COFEN № 374/2011, de 23 de março de 2011. Normatiza o funcionamento do Sistema de Fiscalização do Exercício profissional da Enfermagem e dá outras providências. Brasília (DF): Conselho Federal de Enfermagem (COFEN) [Internet]; 2011 [cited 2018 Sep 13]. Available from: http://www.cofen.gov.br/resoluo-cofen-n-3742011_6590.htm

17. Silva RGM, Nascimento VF, Bertucci AAS, Benicio AC, Ferreira DS, Lopes CCC. Análise reflexiva sobre a importância do Dimensionamento de Pessoal de Enfermagem como ferramenta gerencial. Enferm Br [Internet]. 2016; [cited 2019 Jan 21]; 15(4):221-6. Available from: https://www.researchgate.net/ publication/314180625_Analise_reflexiva_sobre_a_importancia_ do_Dimensionamento_de_Pessoal_de_Enfermagem_como_ ferramenta_gerencial

18. Silva LB. Sistemas de informações em saúde como ferramenta para gestão do SUS. Cad Saúde Desenvolv [Internet]. 2015 Jan-Jun [cited 2019 Jan 22]; 6(4):52-62. Available from: https://www.uninter. com/cadernosuninter/index.php/saude-e-desenvolvimento/article/ view/422

19. Souza GC, Peduzzi M, Silva JAM, Carvalho BG. Trabalho em equipe de enfermagem: circunscrito à profissão ou colaboração interprofissional? Rev Esc Enferm USP [Internet]. 2016 Jun;50(4):642-9. Available from: http://dx.doi.org/10.1590/S0080623420160000500015 